\title{
Disparities in Urban Tourism in the Czech Republic
}

\author{
Jiří Vaníček \\ e-mail: jiri.vanicek@vse.cz
}

Department of Tourism, Faculty of International Relations, University of Economics, Prague, Czech Republic

\begin{abstract}
There are not many European countries with such a significant share of the capital city on tourism (especially incoming tourism) as the Czech Republic. The number of foreign tourists grows significantly in the Czech Republic and so does the share of Prague. All marketing campaigns aiming to get foreign tourists beyond Prague ended inefficiently. The share of Prague on the number of tourists accommodated in standard accommodation facilities per the total number of tourists in the Czech Republic is $62 \%$. Prague is also the only region with a higher number of foreign tourists in comparison with the number of the Czech tourists (85\% of tourists in Prague are foreigners). Furthermore, the offer of sharing economy in the field of accommodation in Prague also exceeds the offer of other Czech cities. Prague is therefore struggling with overtourism in some attractive areas and must deal with unsustainable development.
\end{abstract}

\section{Keywords}

city tourism, overtourism, sharing economy, urban tourism, Prague

JEL classification: Z32 


\section{Introduction}

The number of tourists has grown for seven years in a row in the Czech Republic (CZSO, 2019). Even though the CzechTourism agency has been working on diversification in communication and spreading of awareness of the beauty of other regions in the Czech Republic, most tourists still head for Prague. Some areas (main tourist attractions) are visited by excessive numbers of tourists that reach limits of sustainability. Therefore, it can be perceived as the problem of the so-called overtourism, i.e. overload of tourists in small areas/destinations. Authors follow on their own research that compares attendances in Prague and other cities. High concentration of tourists in one area (i.e. overtourism) causes a few problems - worse conditions for residents, via increased prices of goods/services damage to environment and cultural heritage. In order to improve the overtourism management, it is necessary to examine in detail its roots and prepare preventative and corrective measures. The article introduces results of primary and secondary research that aims to evaluate the position of Prague in the context of tourism in the Czech Republic and to find possible causes of excessive concentration of tourists in one area/destination.

Historical sites and culture have always been the main motivation for travelling and tourism. They are the main motivation for $36 \%$ of tourists, more precisely $41 \%$ of foreign tourists in the Czech Republic (CzechTourism, 2018a). It is therefore undeniable that (not only) capital cities are highly attractive - looking from the historical perspective, they have always been the most important, and therefore, the number of places with architectural/historical value is significantly higher as compared to other cities. Smaller European cities obviously cannot compete with their sights.

A study of the European Parliament (Peeters et al., 2018) uses the annual number of tourists per 100 inhabitants and per $1 \mathrm{~km}^{2}$ for the evaluation of overtourism. The results show clear differences between rural, urban, coastal/islands and heritage/attractions tourism. According to the study, overtourism has impact on the environment (pollution, damage, investment in wrong projects), economy (inflation, economic dependence on tourism, infrastructure costs) and culture (degradation of conditions for residents, conflicts, criminality, loss of identity).

Preveden et al. (2018) point out in his study that most problems arise from a lack of destination planning to prevent overtourism. Most destinations focus on attracting as many tourists as possible, but they do not consider consequences. Preveden therefore offers proactive and reactive measures. Destinations should proactively align tourism strategy with city development strategy; they should build infrastructure also in lowtourism areas; improve segmentation and target various segments across seasons. The reactive measures work with the regulation of capacities of accommodation facilities, active management of sharing economy and restrictions on access to selected areas: entry tickets, dynamic pricing according to the time/season, maximum number of visitors. (Preveden et al., 2018). Furthermore, Jordan et al. (2018) include public education, better on-the-ground tourist management, technological solutions or better monitoring tools for overtourism management. One of the trends of international tourism is dy- 
namic growth of popularity and several visitors in global and European metropolises in the last years. According to the TourMIS (2019), the lowest share of the domestic visitors in 2017 was in Venice (11\%), Prague (14\%), and Amsterdam (18\%).

\section{Theoretical basis}

Capital cities are important for the functioning of almost every country, but surprisingly little has been written about their importance to the country's tourism (Mazanec, 1997). The capital city represents a special case of urban tourism (Page \& Hall, 2003). Some authors argue that capitals do not play an important role in attracting tourists (Law, 2002). According to the Canadian National Capital Commission, the combination of political, cultural and administrative functions is unique to the national metropolis (NCC, 2000). Although the capital is important in terms of national policy, identity and culture, the importance of the status of the capital for tourism has been studied to a limited extent and possibly underestimated. However, capital status is important. As capitals are the administrative and political basis for government operations, trade routes will have to do with both those working in the capital and those who are lobbying for government or influencing decisions. In addition to business related travel, capital cities are also significant for tourism because of their cultural, heritage and symbolic roles. They frequently host major national cultural institutions while they also have a significant wider role in the portrayal, preservation and promotion of national heritage and the showcase national culture (Therborn, 1996). Such a concentration of artistic and cultural institutions will therefore have implications for the travel and active behaviour of tourists with an interest in culture and will contribute to the image of the city. In general, given the increasing competition among cities, the ability to take the advantage of positive cultural images can be considered as a major asset. Cultural opportunities in the capitals a tourist advantage, but their political dimensions do not have to (Law, 2002).

The importance of cities as starting and destination points for visitors has been of carried out little research on urban tourism (Page \& Hall, 2003). Page and Hall (2003) suggest that most of the research that is concerned with urban tourism has not been framed by a global perspective, while Pearce (1995) concurs, suggesting a more macro analysis of urban tourism is required. This lack of attention has the potential to limit our theoretical understanding and ability to contribute to practical knowledge related to urban tourism. Therefore, despite their heterogeneity, national capitals do share a common function, and often this common function is cited as the root of several tourism marketing, planning and development issues.

The City and National Capital Tourism Research Group will focus on the marketing, planning and development issues concerned with tourism in capital cities. Potential topics for exploration include (ATLAS, 2018):

- Tourism as a place promotion or restructuring tool in national capital cities.

- The development and marketing of tourism precincts in capital cities.

- Educational and school tourism. 
- Tourism, national identity and citizenship.

- Capital cities as gateway cities.

- Branding and positioning capital cities.

- Local and visitor perceptions of capital cities and the influence of capital status on visitation.

- The role of politicians in marketing capital cities.

- The role of the media and reporting on images of capital cities.

- Visual representations of national capital cities.

- Conferences, exhibitions and special events as marketing, re-imaging or branding tools.

- Importance of capital cities to visitor segments.

- Engaging residents in marketing national capital cities.

- Marketing national cultural institutions.

- Tourism in emerging national capitals.

- Tourism planning and development issues in capital city tourism, including collaboration and cross border marketing and planning issues.

- International comparisons in marketing and development of national capitals.

According to Law (2002), the main market segments that make up the demand for urban tourism are mainly business travellers, conference and exhibition attendees, shortterm visitors, one-day visitors, people visiting their relatives and friends, long-term visitors who use the city as a starting point for other short-term visits and excursions, and in port cities, participants in cruises and boat trips. Business travellers are the most important as these city visitors make up a large share of tourism on a global scale. It is also necessary to add that the largest market is represented by domestic business visitors. This growing trend in travel is associated primarily with globalization and the company's own organizational structure, where there is a large division of labour today. It is necessary to meet suppliers and customers, cooperate with the development department, monitor technical development and these and many other activities require travel between cities, meetings at fairs and similar activities (Law, 2002). In general, as Williams (2009) writes, it is believed that business travellers represent the largest proportion of city visitors, but we must not forget one day visitors who are an increasingly important group of urban travellers. In recent years, the number of overnight visitors has been boosted by the development of transport, especially in large cities. This trend is particularly significant in Europe. Low-cost airlines also support short-term and day-long city visits.

Demand for urban tourism is linked to the key characteristics of cities, including the fact that seasonality is not so significant. There is a large infrastructure to support leisure and leisure in the city and the associated additional demand for services. The city is a sector with high quality, above-average expenditures and associated high revenues. The urban tourism product may vary from town to town, but it is always made up of a basic supply of goods and services, such as accommodation, cultural facilities and entertainment. These components of the offered urban tourism product can be considered tangible. They are complemented by intangible components, which include something like genius loci and 
the identity of the place (Williams, 2009). According to Jansen-Verbeke (1986), the basic elements of urban tourism are divided into primary ones, which are represented by the specificity of the site in terms of attractions and facilities and the wider environment in which activities are located, secondary such as accommodation and retail and tertiary factors such as parking, information, or traffic signs. Nevertheless, urban tourism is organized around the key points of interest to the visitor, including culture and heritage, accommodation, retail and entertainment and nightlife (Williams, 2009).

After the Velvet Revolution of 1989, the country's democratization and national market reforms led to profound changes in Prague's physical and social structure. In the city centre, many buildings were privatized and restituted to their pre-war owners (Lux \& Mikeszová, 2012). Some properties were transferred to municipal ownership. The historic core gained a prime position in the newly emerging urban economy and its decaying buildings and street were quickly restored. In 1992, the UNESCO agreed to inscribe 866 hectares of Prague's historic centre on its World Heritage List. The pressure for commercial development and the ever-increasing number of international tourists were now the determining forces in the historic core, which has been said to have undergone a process of 'turistification' and turned into a 'tourism ghetto' (Kadlecová \& Fialová, 2010; Dumbrovská \& Fialová, 2014).

While the population of the Prague 1 district has kept decreasing (with 30,561 permanent residents in 2011 - four times fewer than a century before - i.e. only 2.4 per cent of Prague's population, the number of tourist in Prague has kept growing, reaching 6.1 million tourist in 2014 (more than double, compared to 2000). Although smaller in size and population, Prague has ranked among top European destinations for urban tourism such as London, Paris, and Rome. One of the first studies on the impact of tourism in the historic core of Prague was conducted by Simpson (1999), who concluded that the relatively non-regulative approach to development, had already brought about a considerable landuse change in the area. The land use is being rapidly transformed (often from residential to commercial uses). The traditional resident population is being displaced and the overall atmosphere and congestion of the streets is being negatively influenced by the city's visitors. The research, therefore, illustrates a clear need to manage a tourism related activity within the historic core of Prague if its quality of life for residents and the very character which attracted tourists in the first place are not to be eroded substantially.

Soon after the fall of communism in 1989, the Czech capital started to rank among Europe's top tourist destinations, attracting visitors form all over the world with its beautiful architecture, historical atmosphere, and dark yet appealing totalitarian legacies. The number of people visiting the city of 1.2 million has substantially grown, reaching a record of almost 6.1 million visitors and 14.8 million overnight stays in 2014. Despite the multiplying complaints about the 'turistification' of Prague's historic city centre, the authorities have welcomed the increase in tourist flows for its economic benefit. The implications of the turistification process are most tangible in certain parts of the Prague Monument Preserve (PMP), an 8.6 km² area in Prague's historic core, whose valuable assets are being exploited and residents pushed out. Between 1900 and 2001, the number of permanent residents in the PMP decreased from 170,000 to 53,000 (Polívková, 2001). 
The existence of a 'tourist' and 'non-tourist' Prague is affecting the city's social-spatial structures and human ecology (Hoffman \& Musil, 2009). Despite early warnings from academic commentators (Cooper \& Morpeth, 1998; Hoffman \& Musil, 1999; Simpson, 1999), these detrimental effects were long ignored. Only recently have various citizen initiatives and Prague's planning institutions started to react to those negative effects. So far, however, little academic attention has been paid to how the city's residents respond to the impacts of mass tourism (overtourism), particularly by means of protest and resistance.

\section{Methodology}

The aim of this article is to compare the position of Prague as the capital of the Czech Republic with the selected capitals of other European countries and other big cities in the Czech Republic. The results show that the disparity in the distribution of foreign tourists in the Czech Republic compared to the rest of the country is unparalleled in another country. The research is based on the collection of secondary data, both in the Czech Republic and using foreign sources. The sources from which they were drawn are listed in the section on Results.

\section{Results}

\section{Urban tourism in the Czech Republic}

Incoming tourism in the Czech Republic reached the new maximum of number of tourists and overnight stays in 2018. Majority (62\%) of foreign tourists went to Prague. The number of tourists in Prague was 7.9 million out of which 6.7 million (85\%) were guests from abroad in 2018 (PCT, 2018d). The Top 100 Cities Destination Ranking Euromonitor International ranks Prague to fifth/sixth position among the European cities in the number of arrivals in 2012-2017 (PCT, 2018b). Prague took the seventh place among 126 evaluated European cities with total of 18.2 million overnight stays in 2018 (PCT, 2018c). There are eight other cities with over 100,000 inhabitants in the Czech Republic (Brno, Ostrava, Pilsen, Liberec, Olomouc, Ústí nad Labem, Hradec Králové, České Budějovice). They are all regional cities. They have important attractions and an interesting offer for visitors; however, their number of tourists is not as high as in the capital city. 
Table 1 Comparison of the number of tourists in the most important Czech cities in 2018

\begin{tabular}{|l|c|c|c|c|c|c|}
\hline \multirow{4}{*}{} & \multicolumn{2}{|c|}{$\begin{array}{c}\text { Number of guests in accommodation } \\
\text { establishments (in thousands) }\end{array}$} & \multicolumn{3}{|c|}{$\begin{array}{c}\text { Number of overnight stays } \\
\text { (in thousands) }\end{array}$} \\
\cline { 2 - 7 } & Czech & Foreigners & Total & Czech & Foreigners & Total \\
\hline \multirow{3}{*}{ Prague } & 1,221 & 6,674 & 7,892 & 2,116 & 16,133 & 18,249 \\
\cline { 2 - 7 } & $15 \%$ & $85 \%$ & $100 \%$ & $12 \%$ & $88 \%$ & $100 \%$ \\
\hline \multirow{3}{*}{ Pilsen } & 135 & 181 & 316 & 219 & 319 & 538 \\
\cline { 2 - 7 } & $43 \%$ & $57 \%$ & $100 \%$ & $41 \%$ & $59 \%$ & $100 \%$ \\
\hline \multirow{3}{*}{ Brno } & 375 & 426 & 801 & 641 & 796 & 1,411 \\
\cline { 2 - 7 } & $47 \%$ & $53 \%$ & $100 \%$ & $44 \%$ & $56 \%$ & $100 \%$ \\
\hline \multirow{2}{*}{ Karlovy Vary } & 213 & 357 & 570 & 789 & 1,722 & 2,511 \\
\cline { 2 - 7 } & $37 \%$ & $63 \%$ & $100 \%$ & $31 \%$ & $69 \%$ & $100 \%$ \\
\hline
\end{tabular}

Source: CZSO (2019)

Data in Table 1 clearly prove the dominance of Prague as the most attractive city in the country. The extraordinary position of Prague in incoming tourism in the Czech Republic is given by several factors:

- Prague has exceptional culturally historical conditions: The historical core of the city is globally the biggest urban conservation area with extant authentic buildings from the 10th-21st century that reflect a historical development of the city. The historical core has been inscribed in the World Heritage List of UNESCO since 1992. The location of the city at a sloping shore of meander of the Vltava River creates a picturesque scene.

- Prague has an image of an interesting destination and it has a stronger brand than the whole Czech Republic.

- Prague is attractive also thanks to the image of a safe destination.

- Accessibility of Prague is the easiest within the Czech Republic: according to PCT (2018a), Václav Havel International Airport is one of the fastest growing airports in its category in Europe - 16,797,006 travellers in 2018 (year-on-year growth of 9\%), international train and bus connections and great accessibility by individual road network.

- Tourism infrastructure (accommodation and restaurants) has a high capacity and varied structure.

- A wide range of complimentary services.

- Quality products' offer for visitors, especially for cultural tourism.

- Significant part of tourism in Prague is constituted by business tourism - Prague has quality congress centres - there are over 100 big international congresses and 4,500 smaller conferences are held in Prague every year (CZSO, 2019). 
Tourists usually use three routes when they visit the historical area in the Prague city centre. The longest is the Royal Route that goes from the Powder Tower to Prague Castle (approx. $2.7 \mathrm{~km}$ ), the second is the route from the Strahov Monastery via Prague Castle to Klárov (approx. $2 \mathrm{~km}$ ) and the third route goes via the Jewish Quarter starting in the Old Town Square through Maiselova street to the Old New Synagogue (approx. $700 \mathrm{~m}$ ).

Most Prague's visitors start their sightseeing tour of the historical core in the morning (around 9-11 am) at Prague Castle and then go through the historical centre for three kilometres to the Old Town Square. Prague's narrow streets therefore must accommodate a crowd of 30-60 thousand people per day in the season. This creates a high concentration of visitors in peak hours on a very small area.

The number of visitors of individual sights is only an indicative number since most of the Prague's visitors look at sights from the exterior. According to the number of sold tickets, Prague Castle was visited by 2.4 million people, but the total number of visitors (passing through the site) is estimated at eight million - that is 3.3 times more visitors (data for 2017, PCT, 2018e). The same number of tourists visited the Old Town Square and Charles Bridge. A similar situation is in the Jewish Quarter - the Jewish Museum has 716 thousand visitors, but the number of people passing through is significantly higher.

The problem is therefore not the total number of visitors, but their uneven distribution in time and geographical space. It causes a high concentration of people in a limited time on a small area of Prague. The residents are not irritated by the total number of visitors, but they complain about the breach of the quiet hours in the areas with night clubs and about the vandalism done by some groups of visitors.

\section{Share of Prague on tourism in the Czech Republic}

In order to prove the unique position of Prague, several factors were compared in the following tables (Table 2). The most attractive European destination is London, with almost 21 million tourists in 2018. Three more cities were chosen for a better comparison of data: Paris, Rome and Prague (Geerts, 2018). The data from Geerts were used in order to provide a relevant comparison since the data of the Czech Statistical Office show different numbers for Prague. The share of the Czech capital city is the highest in the number of foreign tourists. The number of tourists per one inhabitant is comparable with Paris. 
Table 2 Comparison of tourism intensity in four European metropolises in 2018

\begin{tabular}{|l|l|c|c|c|c|c|}
\hline \multirow{2}{*}{ City } & \multirow{2}{*}{ Country } & $\begin{array}{c}\text { Number of } \\
\text { tourists in } \\
\text { metropolis }\end{array}$ & $\begin{array}{c}\text { Number of } \\
\text { tourists in } \\
\text { country }\end{array}$ & $\begin{array}{c}\text { Number of } \\
\text { inhabitants in } \\
\text { metropolis }\end{array}$ & $\begin{array}{c}\text { Share of } \\
\text { tourists in } \\
\text { metropolis }\end{array}$ & $\begin{array}{c}\text { Number } \\
\text { of tourists per } \\
\text { 1 inhabitant }\end{array}$ \\
\cline { 2 - 6 } & in million & in million & in million & in \% & $\begin{array}{c}\text { tourist/ } \\
\text { inhabitant }\end{array}$ \\
\hline London & GB & 20.8 & 39.2 & 8.8 & 53.0 & 2.4 \\
\hline Paris & F & 16.8 & 87.0 & 2.2 & 19.3 & 7.6 \\
\hline Rome & I & 9.7 & 42.0 & 2.9 & 23.0 & 3.3 \\
\hline Prague & CZ & 9.0 & 12.8 & 1.3 & 70.3 & 6.9 \\
\hline
\end{tabular}

Source: Geerts (2018)

Table 3 shows a number of tourists in Prague in comparison with the whole country. The Czech Statistical Office (CZSO, 2019) monitors the number of accommodated tourists in standard accommodation establishments. All data are therefore comparable for all regions of the Czech Republic. Around 37\% of all tourists are accommodated in Prague - focused on foreigners, it is $63 \%$ of tourists. Only $11 \%$ of Czech tourists are accommodated in Prague since domestic tourists find prices in Prague too high and rather visit Prague only for one day or find accommodation outside Prague and commute daily. The share of Prague in the year-on-year growth of tourist in the Czech Republic was 55\%.

Table 3 Comparison of tourism intensity in Prague and the rest of the Czech Republic in 2018

\begin{tabular}{|l|c|c|c|c|}
\hline & $\begin{array}{c}\text { Number of tourists } \\
\text { in thousands }\end{array}$ & $\begin{array}{c}\text { Foreigners in } \\
\text { thousands }\end{array}$ & $\begin{array}{c}\text { Residents in } \\
\text { thousands }\end{array}$ & $\begin{array}{c}\text { Year-on-year } \\
\text { growth }\end{array}$ \\
\hline Prague & 7,895 & 6,674 & 1.221 & $12.0 \%$ \\
\hline $\begin{array}{l}\text { Czech Republic } \\
\text { (excl. Prague) }\end{array}$ & 13,380 & 3,965 & 9415 & $6.2 \%$ \\
\hline Czech Republic total & 21,275 & 10,639 & 10,636 & $8.1 \%$ \\
\hline Share of Prague & $37.1 \%$ & $62.7 \%$ & $11.5 \%$ & $55 \%$ \\
\hline
\end{tabular}

Source: CZSO (2019)

Table 4 provides the data on accommodation capacity in the Czech Republic. The number of hotels and boarding houses in Prague is almost $9 \%$ of the total number in the Czech Republic. Those facilities are usually bigger - the number of rooms constitutes one fifth of the total number in the country. The number of beds (CZSO, 2019) is slightly lower since there are more single rooms in Prague. Nevertheless, Prague has the highest occupancy (67\%) compared to the rest of the country (50\%). 
Table 4 Prague's share on the accommodation capacity in the Czech Republic in 2018

\begin{tabular}{|l|c|c|c|c|}
\hline & $\begin{array}{c}\text { Number of } \\
\text { establishments }\end{array}$ & $\begin{array}{c}\text { Number } \\
\text { of rooms }\end{array}$ & $\begin{array}{c}\text { Number } \\
\text { of beds }\end{array}$ & $\begin{array}{c}\text { Use } \\
\text { of beds }\end{array}$ \\
\hline Czech Republic & 9,007 & 205,324 & 526,788 & $49.9 \%$ \\
\hline Prague & 787 & 41,617 & 90,891 & $67.0 \%$ \\
\hline Share of Prague & $8.7 \%$ & $20.3 \%$ & $17.3 \%$ & $34 \%$ \\
\hline
\end{tabular}

Source: CZSO (2019)

The structure of accommodation establishments by classification (quality) is also significantly better in Prague than in the rest of the country. Three quarters of all five-star hotels and one third of four-star hotels are in Prague. On the other hand, only every $37^{\text {th }}$ boarding house is in Prague. Specific data are provided in Table 5 below.

Table 5 Prague's share on the accommodation capacity by classification in 2018

\begin{tabular}{|l|c|c|c|c|c|}
\hline & $\begin{array}{c}\text { Hotels } \\
\star \star \star \star \star\end{array}$ & $\begin{array}{c}\text { Hotels } \\
\star \star \star \star\end{array}$ & $\begin{array}{c}\text { Hotels } \\
\star \star \star\end{array}$ & $\begin{array}{c}\text { Boarding } \\
\text { houses }\end{array}$ & $\begin{array}{c}\text { Hotel } \\
\text { Garni }\end{array}$ \\
\hline Czech Republic & 61 & 653 & 1,385 & 3,427 & 111 \\
\hline Prague & 46 & 218 & 210 & 94 & 34 \\
\hline Share of Prague & $75.4 \%$ & $33.4 \%$ & $15.2 \%$ & $2.7 \%$ & $30.6 \%$ \\
\hline
\end{tabular}

Source: CZSO (2019)

Table 6 shows the ten most visited tourist attractions in the Czech Republic. It is obvious that six out of them are in Prague and that four are ZOOs.

Table 6 Ten most visited tourist attractions in the Czech Republic in 2017

\begin{tabular}{|l|l|c|}
\hline Tourist attraction & City & $\begin{array}{c}\text { Number of visitors } \\
\text { (in thousand) }\end{array}$ \\
\hline Prague Castle & Prague & 2,378 \\
\hline Petřín Cable Car & Prague & 2,066 \\
\hline Prague ZOO & Prague & 1,446 \\
\hline AquaPalace Prague & Prague & 836 \\
\hline Aqualand Moravia & Pasohlávky & 721 \\
\hline Petřín Lookout Tower & Prague & 714 \\
\hline Pinkas Synagogue & Prague & 675 \\
\hline ZOO Zlín-Lešná & Zlín & 630 \\
\hline ZOO Dvůr Králové n/L & Dvưr Králové n/L & 525 \\
\hline ZOO Ostrava & Ostrava & 507 \\
\hline
\end{tabular}

Source: CzechTourism (2018b) 
The above-mentioned data show that the situation in Prague is unique and deserves attention of experts. The current tourist/resident ratio and density of tourists are clearly unsustainable.

\section{Prague's share on the number of Airbnb listings in the Czech Republic}

The number of foreign tourists in Prague also increased due to sharing economy, which has made travelling accessible also to economically weak people (low-income families or students). The number of shared accommodations offers (the so-called listings) in Prague $(10,467)$ on the Airbnb platform surpasses the offer of the rest of the country $(13,330)$, almost four times $(3.65 x)$. It is the worst result when compared to the other countries examined in this paper (France, Great Britain, and Italy). The most balanced ratio is in Great Britain - 49,811 listings in London and 52,300 in other cities. Italy and France face an opposite situation - the number of listings in other cities surpasses the offer in the capital city. Table 7 compares the number of listings on Airbnb in selected capital cities and recalculates them per inhabitants.

Table 7 Comparison of the number of the Airbnb listings in the selected metropolises

\begin{tabular}{|l|l|c|c|c|c|c|}
\hline \multirow{2}{*}{ City } & \multirow{2}{*}{ Country } & \multicolumn{2}{|c|}{$\begin{array}{c}\text { Accommodation offer } \\
\text { on Airbnb }\end{array}$} & $\begin{array}{c}\text { Airbnb share } \\
\text { in the } \\
\text { metropolis } \\
\text { in \% }\end{array}$ & $\begin{array}{c}\text { Number of } \\
\text { inhabitants in } \\
\text { the metropolis }\end{array}$ & $\begin{array}{c}\text { Number of } \\
\text { inhabitants } \\
\text { per 1 offer }\end{array}$ \\
& & $\begin{array}{c}\text { in the } \\
\text { metropolis }\end{array}$ & $\begin{array}{c}\text { in the whole } \\
\text { country }\end{array}$ & & 8.8 & 177 \\
\hline London & GB & 49,811 & 102,111 & 48.8 & 2.2 & 71 \\
\hline Paris & F & 30,920 & 92,102 & 33.6 & 2.9 & 123 \\
\hline Rome & I & 23,653 & 97,302 & 24.3 & 1.3 & 124 \\
\hline Prague & CZ & 10,467 & 13,300 & 78.7 & & \\
\hline
\end{tabular}

Source: Airdna.co (2017), Geerts (2018)

The number of listings in capital cities significantly surpasses the number of listings in smaller cities. The most significant difference can be seen in the Czech Republic - there are 17.5 times more listings in Prague than in Brno (the second largest city as regards the number of inhabitants). The disproportionate situation is also in Great Britain - the number of listings in London surpasses Edinburgh seven times. Paris has five times more listings than Nice. There are two times more listings in Rome than in Milan.

The offer of (shared) accommodation is influenced by the size of the market, the number of international airports and the number of the cities attractive to tourists. The reasons for a higher concentration of offers (shared as well as standard) in capital cities are therefore obvious. Even though authors believe in the power of market (and 
freedom), local (municipal) managements are responsible for the quality of residents' lives and preservation of cultural and environmental heritage. It is therefore necessary to introduce some (capacity) rules.

\section{Discussion and conclusion}

The article compares the number of visitors to attractions in Prague with other Czech cities. It compares also the number of standard accommodation facilities and their occupancy. It does not ignore sharing economy and the phenomenon of Airbnb.

Despite the effort of destination managements including the CzechTourism agency, the number of tourists in Prague is several times higher than in the rest of the country. Prague is easily accessible for tourists from distant countries. It has a reputation of a safe city, it is considered cheap, and thanks to its location in the heart of Europe, it is a good starting point for exploring trips around Europe. The data of the CzechTourism (2018a) agency show that $31 \%$ of foreign tourists arrive in the Czech Republic by airplane and $45 \%$ arrive by car. Considering the quality of the road infrastructure (ex. highway to Brno or to Moravia), it is obvious that tourists do not want to travel beyond Prague. The data also show that 52\% of tourists are in Prague for the first time - trips out of Prague are therefore more likely to happen during their next visits. That is also related to the motivation of tourists coming to the Czech Republic, especially for cultural sightseeing (59\% of respondents). The high concentration of cultural sights in Prague is reflected in a high concentration of tourists (PCT, 2018d).

Problems arise from the high concentration of tourists in a few areas - only some places in Prague are overcrowded and suffer from negative effects of overtourism. A better flow of tourists in Prague could be arranged by better tourist direction signs, higher awareness about alternative routes and general education of tourists and residents on negative effects of excessive attendance. In order to protect some sights, it would be beneficial to launch daily quotas for a maximum number of visitors, alternatively decrease the entrance fee in less exposed times/seasons, or to offer an attractive accompanying program. The increased costs for repairs of damage caused by overtourism might be partially compensated by increased spa and recreational fees.

Overtourism is a problem of modern society - it is a result of luxury lifestyle we have. Travelling is accessible to more and more people, and therefore the number of visitors in (capital) cities increases. The Ministry for Regional Development should cooperate with the CzechTourism agency and reconsider the strategy of cities' development together with the importance of tourism for the whole ecosystem of the Czech Republic. The number of tourists in Prague will most likely continue increasing, however, it is necessary to prepare a plan for remedial action and a detailed plan to prevent future negative effects.

The strategy of constant growth of tourism is rooted in the history of many cities, but its consequences are not considered. The capacity of tourist destinations is limited just as the capacity of means of transport or accommodation establishments. Even though 
everyone is trying to maximize profit, it is not always in the interest of inhabitants, environment, historical sites or tourists themselves. Overtourism, or excessive concentration of tourists in a destination, endangers several cities across Europe - and Prague, precisely its historical core, is one of them.

The number of visitors at the Royal Route grows every year as a result of the constantly growing number of Prague visitors. The estimated number of visitors at the Royal Route is 20 million people per year. It is based on the estimate of the total number of Prague Castle visitors ( 8 million in 2018). However, it needs to be multiplied by at least 2.5 because Prague Castle is visited only once, but the Route is used by a visitor at least 2-3 times during the stay in Prague. The most exposed is the part between the Old Town Square and Charles Bridge.

Most tourists visit the historical core, but only 3\% are aware of the Royal Route. Considering the fact that approximately $10 \%$ of visitors walk the Route with a tour guide, it means that even tour guides do not stress out the historical value of the place.

The architectural attractions at the Royal Route were created over centuries and they represent the base of the Route's potential (historical city buildings, aristocratic palaces, sacral buildings, city infrastructure - the Powder Tower, town hall, Charles Bridge, Clementinum). Other attractions were created for the developing tourism and they include galleries, museums, or theatres. The majority of museums - Chocolate museum, Torture museum, Wax museum, Apple museum, Ghost and Legends museum, Gingerbread museum, Illusion Art museum - do not have a historical link to the Royal Route, expositions are not of good quality, but they have high entrance fee and benefit from their location. Their number is slowly increasing. There is no museum or exposition devoted to the phenomenon of the Royal Route.

\section{References}

Airdna.co. (2019). Short-term rental data $\mathcal{E}$ analytics. Retrieved March 24, 2019 from https://www. airdna.co/.

ATLAS. (2018). Special Interest Group. Retrieved March 24, 2019 from http://www.atlas-euro.org/ sig_city.aspx\#activities\%202018.

Cooper, C., \& Morpeth, N. (1998). The impact of tourism on residential experience in Centraleastern Europe: the development of a new legitimation crisis in the Czech Republic. Urban Studies, 32 (2), 2253-2275.

CzechTourism. (2018a). Domáci a př́jezdový cestovni ruch: Prezentace výsledků za 4. čturtleti 2017 - 2. čtvrtleti 2018 (Domestic and incoming tourism: Presentation of 4Q 2017 - 2Q 2018 Results). Retrieved April 17, 2019 from https://czechtourism.cz/getattachment/Institut-turismu/Marketingovy-vyzkum/Tracking-DCR-PCR/Reporty/Tracking-DCR-PCR-2Q-2018/DCR-a-PCR-4Q2017,1Q,2Q-2018_GfK_19092018-PREZENTACE.pdf.aspx?ext=.pdf.

CzechTourism. (2018b). Návště̀nost turistických cílů 2017 (Visit rate of tourist destinations 2017). Retrieved April 17, 2019 from https://czechtourism.cz/getattachment/Pro-media/Tiskovezpravy/Navstevnost-turistickych-cilu-v-CR-lakaji-historic/Czech_Tourism_nej_turisticke_cile. pdf.aspx?ext $=$.pdf. 
CZSO (Czech Statistical Office). (2019). Public Database [statistics]. Retrieved from https://vdb2. czso.cz/vdbvo2/faces/en/index.jsf.

Dumbrovská, V., \& Fialová, D. (2014). Tourist intensity in capital cities in Central Europe: comparation analysis of tourism in Prague, Vienna and Budapest. Czech Journal of Tourism, 3(1), 5-26. DOI: $10.2478 /$ cjot-2014-0001.

Geerts, W. (2018). Top 100 City Destinations 2018. Euromonitor International. Retrieved from https://blog.euromonitor.com/top-100-city-destinations-2018-the-irresistible-draw-of-cities/ .

Hoffman, L., \& Musil, J. (2009). Prague, the tourist and the post-industrial city. Chicago: Great Cities Institute, University of Illinois at Chicago.

Jansen-Verbeke, M. (1986). Inner-city tourism: resources, tourist and promoters. Annals of Tourism Research, 13(2), 79-100. DOI: 10.1016/0160-7383(86)90058-7.

Jordan, P., Pastras, P., \& Psarros, M. (2018). Managing Tourism Growth in Europe: The ECM Toolbox. Retrieved April 17, 2019 from https://www.ucm.es/data/cont/media/www/pag-107272/2018Managing\%20Tourism\%20Growth\%20in\%20Europe\%20The\%20ECM\%20Toolbox.pdf.

Kadlecová, V., \& Fialova, D. (2010). Královská cesta v Praze - vizitka Česka (The Royal Route in Prague - Czech "shop window"). In Aktuálni problémy cestovního ruchu (Current problems of tourism). Retrieved June 17, 2019 from http://geography.c-z/wp-onlent/uploods/2009/11/ pozvánka.pdf.

Law, C. (2002). Urban Tourism: The Visitor Economy and the Growth of Large Cities. London: Continuum.

Lux, M., \& Mikeszová, M. (2012). Property restitution and private rental housing in transition: the case of the Czech Republic. Housing Studies, 27(1), 77-96. DOI: 10.1080/02673037.2012.629643.

Mazanec, J. (1997). International City Tourism: Analysis and Strategy. London: Pinter.

NCG (National Capital Commission). (2000). Planning Canada's Capital Region. Ottawa: National Capital Commission.

Page, S., \& Hall, C. M. (2003). Managing Urban Tourism. Harlow: Prentice-Hall.

PCT (Prague City Tourism). (2018a). Letiště Václava Havla Praha v číslech (Václav Havel Airport Prague in numbers). Retrieved June 17, 2019 from https://www. praguecitytourism.cz/file/ edee/statistiky-a-analyzy/letiste/letiste-praha-v-cislech-2018.pdf.

PCT (Prague City Tourism). (2018b). Euromonitor International - Top 100 Cities Destination Ranking. Retrieved June 17, 2019 from https://www.praguecitytourism.cz/file/edee/statistiky-a-analyzy/ praha-v-mezinarodnim-srovnani/euromonitor-international-top-100-cities-destination-ranking.pdf.

PCT (Prague City Tourism). (2018c). ECM Benchmarking Report 2017-2018. Retrieved June 17, 2019 from https://www.praguecitytourism.cz/file/edee/statistiky-a-analyzy/praha-v-mezinarodnimsrovnani/the-european-cities-marketing-benchmarking-report-2017-2018-cj.pdf.

PCT (Prague City Tourism). (2018d). Praha - Př́jezdový cestovni ruch v roce 2017 (Incoming tourism in 2017). Retrieved June 17, 2019 from https://www.praguecitytourism.cz/file/edee/statistikya-analyzy/nejnovejsi-analyzy/a-analyza-2017_internet.pdf.

Pearce, D. G. (1995). Tourism Today: A Geographical Analysis. 2nd ed. Harlow: Pearson Education.

Peeters, P., Gössling, S., Klijs, J., Milano, C., Novelli, M., Dijkmans, C., Eijgelaar, E., Hartman, S., Heslinga, J., Isaac, R., Mitas, O., Moretti, S., Nawijn, J., Papp, B., \& Postma, A. (2018). Research for TRAN Committee - Overtourism: impact and possible policy responses. European Parliament, Policy Department for Structural and Cohesion Policies, Brussels. ISBN 978-92-846-4406-3.

Polívková, H. (2001). Aktualizace studie Pražské památková rezervace (Update of the Prague Historical Reserve Study). Věstnik Klubu Za starou Prahu, 1(2). Retrieved from http://story-web. zastarouprahu.cz/ruzne/ppr1.htm. 
Preveden, V., Mirkovic, M. Gratzer, \& Schenk, O. (2018). Protecting your city from overtourism: European city tourism study 2018. Roland Berger, 20 p. Retrieved from April 01, 2019 from https:// www.rolandberger.com/publications/publication_pdf/roland_berger_european_city_tourism_2018.pdf.

Simpson, F. (1999). Tourist impact in the historic centre of Prague: resident and visitors' perceptions of the historic built environment. Geographical Journal, 165(2), 173-83. DOI: 10.2307/3060415.

Therborn, G. (1996). Monumental Europe: The National Years of the Iconography of European Capital Cities. Gothenberg: University of Gothenberg.

TourMIS. (2019). Nights and arrivals in the cities. Retrieved April 17, 2019 from http://www.tourmis.info/cgi-bin/tmintro.pl

Williams, S. (2009). Tourism Geography: A new synthesis. 2nd ed. Oxon, New York: Routledge, 309 p. 